\title{
New Trends in Traditional Farming Methods of Rice Cultivation: with special reference to Ulpotha village in Sri Lanka
}

\author{
J.A PrasanshaKumari ${ }^{1}$, Senior Lecturer ${ }^{2}$ \\ ${ }^{1,2}$ Department of Economics, University of Kelaniya, Sri Lanka
}

\begin{abstract}
: this research intends to identify and analyze the new trends of usage the traditional farming methods to modern paddy cultivation. Information gathered through conducting interviews with total of 200 farmers in selected paddy cultivation areas in Kurunegalla district. As well as this research utilized by case study and observation in Ulpotha Traditional Village, Galgamuwa of Sri Lanka. Secondary data collected from books, articles, relevant websites and other relevant documents. Collected data analyzed by descriptive research methodology. Outcomes are there is growing interest in usage the traditional farming methods to the small consumption level paddy lands that have emerged during the last few decades As well asthe researchrevealed that traditional farming method has identified the ecofriendly farming practices to restrict long term side effects inherited from the modern methods. The study find out demand of traditional rice varieties has being growing among the community as health and nutrition purpose
\end{abstract}

Keywords: Traditional farming, organic, inorganic, paddy cultivation

\section{Introduction}

Rice is main food as well as paddy cultivation is the major agriculture cultivation in the Sri Lanka. Currently, around 708,000 hectares of land cultivated in Sri Lanka for paddy, There are two cultivation seasons namely; Maha and Yala which are synonymous with two monsoons.. Department of Agriculture is expecting a paddy harvest of 2.8 million MT in the Mahaseason2014/2015[1].However Sri Lanka exports some quantity of rice every year

Many researchers and policy makers are concerning the development and sufficient of agriculture sector as well as paddy cultivation in the country. Around the world, there is growing interest in finding alternatives to the modern industrial farming methods that have merged during the 20th century. Traditional farming method has identified as the success method for the high yield [2], increased production, profitability, etc. Sri Lanka has experienced many changes over the last century which has had a significant impact on traditional rice farming in the country.

There is no clear universally accepted definition of traditional farming. However, we can look at some important ideals surrounding the term traditional farming. Traditional farming is the ancient food production system and the original type of agriculture is has been practiced for thousands of years. Traditional farming is not only the world's oldest farming method but also the main source of improving phase of farming technology like conventional, modern and organic farming it promotegenetic diversity too[3].

Methods of traditional agriculturepracticesrepresents the original method of farming that developed through the interaction of social and environmental systems.

With the highly productive and competitive nature, modern industrialagriculturesector had to face many serious economic, social environmentalissues such as the loss of biodiversity and soil fertility, the loss of farmer's income, higher suicide rates among farmers due to their inability to pay off debts. On the other hand, theircosts of inputs (for seeds, weedicides and pesticides, etc.)are higher than their earnings.

According to this situation, traditional agriculture methods are appropriate methods to solve some environmental problems which was created from modern agricultural practices. However traditional farmers generation to generation is being lost.[4] Efforts are therefore necessary to protect this valuable traditional information, and it is time to begin to combine traditional and modern forms of farming. In this paper intends identify the modern tends in traditional farming methods in paddy cultivation.

\section{Research Objective}

This study attempts to analyze the traditional farming methods used in the area and usage of those farming methods to modern paddy cultivation process.

\section{Research Methodology}

Manly the information has been gathering through conducting structured interviews with farmers in four industrial paddy cultivation areas in Kurunegalla district of Sri Lanka. Total intended sample of farmers to 
be interviewed is 100 . This research utilized by case study and observation in Ulpotha village, Galgamuwa located in North Western Province where the majority of the rice is grown for personal consumption with highly using traditional agricultural practices. Conducted interviews with a selected sample of GoviNiyamakas's, farming leaders, knowledgably people and farmers in the areas.Thecollected data was analyzed usingdescriptive research method

\section{Data Analysis and Discussion}

Traditional system practiced by farmers includes: i) cultivation of traditional rice varieties; ii) use of organic fertilizers (straw, green manure, cow dung, poultry manure, liquid fertilizer etc.); iii) management of weeds through hand weeding, mechanical weeding, and water management; iv) management of pest and diseases by practicing rituals, maintaining bio-diversity, and using bio-pesticides; and v) management of available water without leading to moisture stress [2].

According to the case study, the small scale farmers (in the consumption level paddy cultivation) in Ulpotha traditional village trend to use various traditional farming practices in their paddy fields. On the other hand, thestudy was revealed that large scale modern paddy cultivation areas in Sri Lanka were highly using modern farming practices than consumption level paddy cultivation areas.

According to case study famers in Ulpotha traditional village totallycultivate the traditional varieties such as Suwandel, Rathdel, Kaluheenati, Ma-Wee, Kuruluthuda, Pachchaperumal, Madathawalu, Hetadha Wee, Hondarawalu, Girisa, Herathbanda, kuruwee, dikwee and Heenati.

The farmers were modern industrial paddy areas using new and improved high yielding crop varieties of grains to increase food production, Incorporation of pest and disease resistance, semi dwarf plant type, response to fertilizer, better grain quality. As illustrated in Table I, 36 percent of the farmers cultivate only traditional varieties in modern paddy areas. While the 56 percent cultivate the hybrid varieties. 26 percent use both traditional and hybrid varieties for their cultivation.

Table IUsage of Rice Varieties in Modern Paddy Areas

\begin{tabular}{|l|c|c|c|}
\hline Rice Varieties & No of Famers & \% & \\
\hline Traditional & 36 & 18 & \\
\hline Hybrid & 108 & 54 & \\
Both & 56 & 28 & \\
Total & 200 & 100 & \\
\hline
\end{tabular}

As illustrated in Table I, 56 percent of the farmers cultivate only hybridvarieties in modern paddy areas. While the 18 percent cultivate the traditional varieties 26 percent use both traditional and hybrid varieties for their cultivation.

In Ulpotha traditional village crops are protected from bugs and pests using traditional and biological methods [5]. These start with the choosing of auspicious times for planting and the making and keeping of ritual vows to the spirits of the land. Biological means, such as the use of powdered neem seeds, dried makra leaves, crushed coconut shavings, sap from the jack fruit, cactus milk, and branches of the Kaduru tree, bamboo leaves and riverbed sand, are all employed when required and appropriate to deal with any infestations.

Famers in Ulpotha traditional villagenaturally not used inorganic fertilizers and pesticides on the land. The farmers in Ulpotha village highly used to age-old bio-dynamic formulas, traditional rituals, and biodiversity are used to ensure a healthy harvest. In order to protect the natural environment and healthy harvest, famertotally using organic fertilizer for cultivating traditional rice varieties. Sunflower, paddy husk, green materials, livestock waste, household waste andother waste used as organic fertilizer. Manly they used compost as organic fertilizers, In addition parts of or total plant can be incorporate in to paddy field as a source of nitrogen. These green materials become quickly decomposing with buffalo ploughing.

Table II indicates the usage of fertilizer among farmers in modern industrial paddy area. 122 famers totally using inorganic fertilizer for cultivate traditional rice varieties such as pesticides and weedicides. 46 famers using both fertilizer to their cultivation. Sunflower, paddy husk, livestock waste and other waste used as organic fertilizer. In addition the house hold waste also used to produce compost. As well as farmers use green materials as organic fertilizers, parts of or total plant can be incorporate in to paddy field as a source of nitrogen. These materials become quickly decomposing with ploughing.

Table II Usageof Fertilizer

\begin{tabular}{|l|l|l|}
\hline Fertilizer & No of Famers & $\%$ \\
\hline Organic & 122 & 61 \\
\hline Inorganic & 32 & 16 \\
Both & 46 & 23 \\
Total & 200 & 100 \\
\hline
\end{tabular}


Small paddy cultivation lands in Ulpotha traditional village, ploughing and threshing of the paddy are carried out using buffalo, as the use of tractors is are less employed. The latter tend to break through the crust that retain water in paddy fields, resulting in the need for far greater amounts of irrigation. They also tend to dig up the soil too deeply, bringing less fertile soil to the surface to the detriment of the crops. Buffalo ploughing, on the other hand, do not cause these issues and do not produce environmental pollution, while they do produce useful fertilizer to soil.According to the research, it was revealed that large scale modern paddy cultivation areaswere highly using machines and tractors for land preparation, processing, harvesting and storing because more land was cultivated for fulfill the international rice demand, hence small ploughs with buffaloes and weren't enough for large paddy field

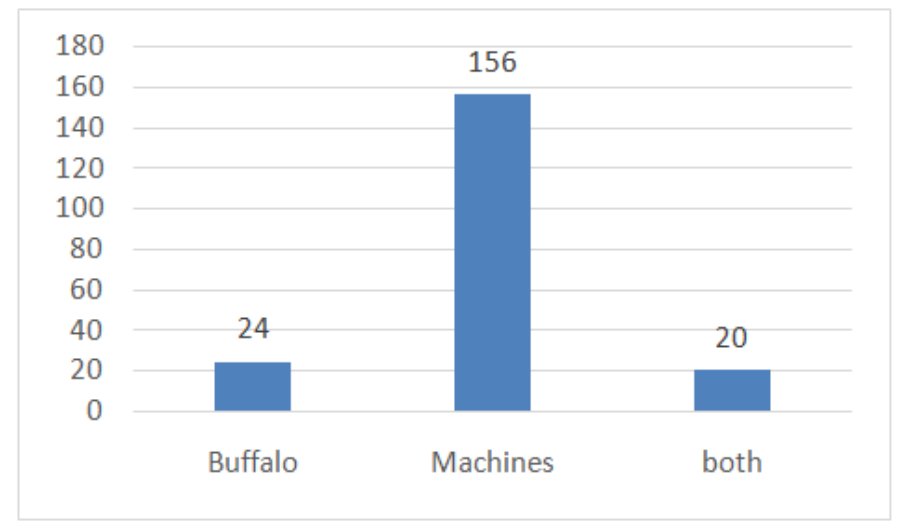

Fig. 1Ploughing and Threshing Methods

As shown in the figure I, 156 famers in modern paddy areas ploughing and threshing are carried out using Tractors and machines, while 24 farmers using buffalo for their cultivation process. The study identify that usage of buffalo ploughing was depended on quantity of land and purpose of cultivation.

\section{Reasons for using Traditional Farming Methods}

Sri Lanka has experienced many changes over the last century which has had a significant impact on traditional rice farming in the country. The new plants were not resistant to pests and diseases, therefore agrochemicals (Pesticides and Weedicides) were introduced to help them out. In addition the soil needed to be highly productive and organic fertilizer need time to decompose. Plants could access the nutrients from inorganic fertilizer faster. On the other hand modern paddy areas have suffer some economic and social problems. Such as loss of jobs, mainly for small farmers and, inability to pay off debts - their input costs for seeds, pesticides, etc. are often much higher than their earnings.

The research was revealed that modern industrial paddy farming area in Kurunegala district is prone to some issues. Several problems were associated in the area such as crop suffering from micronutrient deficiencies such as whitening, yellowing and retardation of growth. Further, these crops were more susceptible to pest and disease attacks.

First, the mechanization. Large ploughs which could plough up to 12 inches were introduced. The earlier ploughs tilled the soil only up to four to six inches. There is a hardpan underneath the soil which was left undisturbed [5]. The water and nutrients were thus at an optimum level "The hardpan was formed by generations of agriculture. The buffalo's feet can penetrate up to six inches of soil and when ploughed, it formed the hardpan underneath. The big plough however breaks the soil up to one foot, breaking up the hardpan in the process. The water is percolating inside as also are the nutrients. In the earlier days of traditional farming, water was filled two to three inches above the soil layer to control weeds "Now, when the water percolates down to 12 inches below soil level, the rice plants cannot extend that far down, but weeds can. So the solution is to apply weedicides - more agrochemicals.

Nutrients have also percolated deep down with the water so inorganic fertilizers are added. But inorganic fertilizer dissolve easily in water, and so percolate down because of the lack of a hardpan. Crop plants need micronutrients in addition to Nitrogen, Phosphorous and Potassium. Inorganic fertilizer do not have these micronutrients although traditional organic fertilizer such as compost do. The crop therefore suffers from a variety of micronutrient deficiencies such as whitening, yellowing, and retardation of growth. Plants are susceptible to pest and disease attack. According to this situation modern farmer trend to reapply the traditional methods in modern rice farming system as an ecofriendly agricultural practices.

Other reason of use to traditional farming method in part due to their unique health benefits. For examples, the traditional varieties have lower sugar content, making them an appealing choice for consumers 
who are diabetic, overweight, or monitoring their sugar intake. They have higher amounts of glutamic acid, fiber, and vitamins. Some people also credit traditional varieties with other health benefits, such as cooling the body in Ayurveda treatments, improving vocal clarity, and alleviating rashes, feeding mother

The study identified that the modern industrial farmers have used traditional rice varieties as a main traditional agricultural practice. There are three reasons for using traditional rice varieties in modern industrial paddy areas.

1. Farmers $\backslash$ trend to use various traditional farming practices to restrict long term side effects inherited from the modern methods.

2. As an ecofriendly agricultural practice

3. For health and nutrition purpose

\section{New Trends in Usage Traditional Farming Methods in SriLanka}

The research identified some areas used in the traditional farming methods that help to build up some uniqueness which are different from other paddy cultivation methods. For instance, Ulpotha has been identified as one important place in Sri Lanka well known traditional farming methods and rice varieties. This village is more popular among local and international visitors as a place practicing traditional farming techniques.

Traditional farming methods are frequently used by small farmers who cultivate paddy for family consumption and to meet the small scale demand from target groups. According to the case study, it revealed a new trend in Sri Lanka to cultivate traditional rice varieties predominately using organic fertilizers for mainly family consumptions. Due to the traditional varieties which have lower sugar content, they make an appealing choice for consumers who are diabetic, overweight, or monitoring their sugar intake. Farmers tend to cultivate traditional varieties for concerning about the high health benefits of consuming the traditional varieties. In Addition,

the research had identified that the small farmers have adopted traditional farming to fulfill demand of target groups for instance: owners of Ayurveda hospital and hotels and high income consumers, Super markets etc. In addition, this research identified that traditional farming methods are frequently used by educated farmers who adopted rice cultivation as an additional income and a hobby. For instance school retired teachers, spiritual leaders, and retired employees from government and private sectors. Mainly they cultivate rice for family consumption.

The research revealed a new trend of the awareness on the traditional rice varieties had increased. The percentage of suffering health disease had increased in past decade. Due to this situation, people tend to concern about their food culture and food habits at present. On the other hand scientific researchers, Ayurveda doctors, and health organization have been promoting traditional rice varieties for health purposes. They often discuss the importance of consuming traditional and organic foods by public media. The research identified that people had enough understand about the importance of consuming the traditional varieties in part due to their unique health benefits as mentioned above

According to the research outcome, demand and price level of traditional rice varieties and organic foods have been increasing during the last 3-5 years. The demand of traditional varieties has increased in international markets and among local high income consumers. Modern markets have allocated some special areas for traditional rice varieties and organic foods. For instance, Arpico Super Center, KEELS Super Center and Cargeels Food City Sri Lanka. Price level of all the traditional rice varieties is doubled than hybrid rice varieties. Table III presents the difference of price level of traditional varieties and hybrid varieties in Arpico Super Center, Sri Laka

Table IIIPrice Level of Rice Varieties in the Arpico Super Centre
\begin{tabular}{|l|l|l|l|}
\hline $\begin{array}{l}\text { Hybrid } \\
\text { verities }\end{array}$ & Price (Rs) & $\begin{array}{l}\text { Traditional } \\
\text { varieties }\end{array}$ & Price (Rs) \\
\hline Samba & 72 & Suwadel & 205 \\
\hline Nadu & 70 & Madathwalu & 205 \\
\hline RathuKekulu: & 70 & Heenati & 205 \\
\hline
\end{tabular}

The research identified the new trends inusage of traditional rice varieties in modern cooperative and government sectors. For instance,CIC Agri Businesses (Private) Limited is a subsidiary of $\underline{\text { CIC, which }}$ encompasses all the agriculture related businesses that are carried out within the CIC Group[6]. This is a one of lager comparative sector agri business company which is concerning about the traditional rice varieties in modern agricultural society. CIC as an Agri Business Company ensures that all business operations and activities are carried out in an environmentally friendly manner and with the minimum impact to the environment. CIC isproducing various rice verities for modern local and international market. There are three traditional rice varieties with unique taste. They are Madathawalu, Kaluheenati and Suwadel. The demand and price level for above traditional varieties is high in the modern markets 90. 
The Ministry of Agriculture, Ministry of Economic Development, Buddhist Associations and Traditional organizations are promoting to use traditional farming methods in paddy cultivation areas. The Ministry of Agriculture, Sri Lanka plans to cultivate 100,000 acres of land with paddy by using traditional methods. According to this system of conventional paddy cultivation, farmers would not use any chemicals. Its aim is to breed and propagate local rice varieties and provide seeds and ecological awareness to farmers. It strives to do this by training farmers in ecological farming, building awareness among farmers to shift to ecological farming, assisting ecological paddy farmers to market their products at fair prices, and developing a more direct rice chain from farmer to consumer and ensure a price fair to both. Among its different actions, possibly the most important is the collection and recording of traditional varieties and associated traditional knowledge gathered from farmers throughout the country who meet every season to share seeds.In additional, Ministry of Economic Development has lunched the programmeDiviNeguma and this programme also promotes to cultivate traditional rice varieties by using organic fertilizers.

\section{VII.Conclusion}

. They use this crops for their family consumption. The research revealed the demand of traditional rice verities has been growing in last decades government, non governmental organization and Ayurveda medicine have promoting the traditional rice varieties as healthy foods.

\section{References}

[1] Agriculture and Environmental Statistics Division, Paddy statistics, Department of Census and Statistics, Colombo, Sri Lanka

[2] Darmasena,P.B, Traditional Rice Farming in Sri Lanka: Still Viable with ClimateChange, IPS CIMATE net blog, Climate change policy network, Sri Lanka

[3] Traditional Farming from http://www.agricultureinnepal.com

[4] Traditional agriculture practices, Documentary film festival, 2013, October from HYPERLINK "http:/2013 festivalalimenterre.cz/en/vice-k-tematu/tradicni-a-udrzitelne-praki-v-zemedelstvi/'http://2013.festivalalimenterre.cz/en/vice-ktematu/tradicni-a-udrzitelne-prakti..

[5] eb/cic-agribusinesses-private-limited.html 